\title{
Parasitism of Ixodes (Multidentatus) auritulus Neumann (Acari: Ixodidae) on Birds from the City of Curitiba, State of Paraná, Southern Brazil
}

\author{
Márcia Arzua, Darci Moraes Barros-Battesti*/+ \\ Museu de História Natural Capão da Imbuia, Departamento de Zoológico, Prefeitura Municipal de Curitiba, Rua \\ Benedito Conceição 407, 82810-080 Curitiba, PR, Brasil *Laboratório de Artrópodes, Instituto Butantan, Av. \\ Vital Brazil 1500, 05503-900 São Paulo, SP, Brasil
}

The tick-bird relationship of 56 specimens of birds (Passeriformes and Columbiformes) collected in the city of Curitiba, State of Paraná, between 1990 and 1995, among which 102 specimens of Ixodes (Multidentatus) auritulus were found and analyzed. New host records were also produced including the first report of I. auritulus on a Columbiformes bird in Brazil.

Key words: Ixodes auritulus - tick-bird relationship - new host birds - Paraná - Brazil

The description of Ixodes auritulus Neumann, 1904, was based on four females collected by Labrun on an undetermined bird from Punta Arenas, Chile. Three of the four type specimens are deposited in the Paris Museum of Natural History (access nos. 2474 and 2483) and one in the École Nationale de Vétérinaire, Toulouse (Arthur 1960). Dumbleton (1953), in his study of ticks of the New Zealand sub-region, described a male collected together with a female and a nymph, in a petrel's (Pelecanoides urinatrix) nest material, as $I$. auritulus. Nevertheless Arthur (1960), highlighted characters which distinguished the New Zealand populations from those I. auritulus sens. str., and Dumbleton (1961) considered the New Zealand forms collected on seabirds as subspecies designating I. auritulus zealandicus subsp. nov., and he considered the American forms collected on land birds as I. auritulus auritulus. Kohls and Clifford (1966) described the male of I. auritulus auritulus from Rio El Ganso, Magallanes, Chile, February 26, 1961, which is near Punta Arenas, the type area of I. auritulus. This specimen was deposited in the Rocky Mountain Laboratory (RML 37869). Clifford et al. (1973) included this species in the Multidentatus subgenus.

In Brazil, specimens of I. (Multidentatus) auritulus, were collected on Knipolegus nigerrimus (Tyrannidae: Passeriformes), Thamnophilus

\footnotetext{
This work was supported in part by Conselho Nacional de Desenvolvimento Científico e Tecnológico (CNPq). ${ }^{+}$Corresponding author. Fax: +55 -11- 815.1505. E-mail: dbattest@usp.br

Received 1 April 1999

Accepted 7 June 1999
}

ruficapillus and T. caerulescens (Formicariidae: Passeriformes) birds from Serra de Itatiaia, Atlantic Forest, State of Rio de Janeiro in 1922 (Cooley $\&$ Kohls 1945). However, these specimens were deposited in Bureau of Animal Industry, U.S. Department Agriculture, accession no. (BAI-25088, one female, on $K$. nigerrimus collected by EG Holt in Feb. 2, 1922); U.S. National Museum, accession no. (Nat'l Mus-287, one female, on Tamnophilus ruficapillus) and (Nat'l Mus-322, five females, on T. caerulescens) collected by EA Chapin, in Feb. 2, and Feb. 10, 1922, respectively.

Specimens of I. auritulus were collected on Turdidae for the first time in the State of Paraná, during bird banding in the Passaúna Park of the city of Curitiba, during 1990 to 1992 (Arzua et al. 1994). These results led Marini et al. (1996) to investigate the prevalence of ticks on birds from mountain and lowland forest areas of the State of Paraná. However, during their investigation (from 1991 to 1995), they observed predominant infestation by Amblyomma larvae (94\%) as oppossed to immature stages of Ixodes (not auritulus) (6\%).

The purpose of this work was to investigate the mainly green areas (parks) of the city of Curitiba in order to increase the information available on the relationship between I. auritulus and birds and providing new host records.

\section{MATERIALS AND METHODS}

The city of Curitiba $\left(25^{\circ} 25^{\prime} 40^{\prime}\right.$ ' $\mathrm{S}, 49^{\circ} 16^{\prime}$ 23 "'W), with $430 \mathrm{~km}^{2}$, is located in the Curitiba uplands sub-region (Maack 1968), $934.57 \mathrm{~m}$ above sea level (IBGE 1995). Subtropical forests with Araucaria angustifolia, which predominated in this region in the past, are now reduced to small patches with altered primary forest or secondary vegetation and some preserved areas in the city and its 
surroundings. According to Koppen's classification, the climate type is $\mathrm{Cfb}$ (mesothermic-humid with well distributed rainfall and mild summers), with an annual rainfall ranging from 1,250 to 2,000 $\mathrm{mm}^{3}$, and an annual mean temperature ranging from $14^{\circ} \mathrm{C}$ to $19^{\circ} \mathrm{C}$ (Coelho 1990).

For this study, five parks in the city of Curitiba, and one adjacent area to the city of Almirante Tamandaré (Primavera Park with $800,000 \mathrm{~m}^{2}$ ) were investigated. Investigations in the Passaúna Park $\left(6,500.000 \mathrm{~m}^{2}\right)$ began in 1990 during bird banding. As of January 1992, investigations began in the Barigui $\left(1,400.000 \mathrm{~m}^{2}\right)$, Iguaçu $\left(8,264.316 \mathrm{~m}^{2}\right)$ and Reinhardt Maack $\left(78,000 \mathrm{~m}^{2}\right)$ parks. The Barreirinha $\left(275,380 \mathrm{~m}^{2}\right)$ and Primavera parks, were investigated only during 1995 . All the collections ended in December 1995. These parks are open to public visitation, suffering a great deal of anthropic activity over weekends.

From 1992 to 1995, the birds were captured every six weeks in all the areas, using 20 "mistnet" nets of $12 \mathrm{~m} \mathrm{x} 3 \mathrm{~m}$, distributed $20 \mathrm{~cm}$ above the ground. During every capture, the nets were opened around sunrise and operated until late afternoon.

Each captured bird was banded and visually examined for ticks using a magnifying hand glass. Ticks were found around the hosts' head, eyes and neck. The ticks were collected with tweezers and preserved in $70^{\circ}$ ethanol for taxonomic identification. After banding, the birds were set free.

The taxonomical identification of the hosts is based on the scheme at Meyer De Schauensee (1983). For bird families, the nomenclature proposed by Scherer Neto and Straube (1995) was used. Adult ticks were identified according to Nuttall and Warburton (1911), and Mendez-Arocha and Ortiz (1958). Nymphs were identified according to Cooley and Kohls (1945) and Durden and Keirans (1996). For larvae we used the description of Clifford et al. (1973). All specimens of ticks were deposited in the Museu de História Natural Capão da Imbuia (MHNCI), Curitiba.

The tick infestation indices were calculated by the arithmetic mean (mean number of ticks among the individuals of a taxon, excluding non infested individuals) to establish the infestation rate for each taxon.

From 1992 to 1995, the monthly rainfall indices and monthly average temperature were supplied by the Sistema Meteorológico do Paraná (Simepar).

Spearman rank correlations $\left(\mathrm{r}_{\mathrm{s}}\right)$ between larvae, nymph and adult numbers of I. auritulus and meteorological data (rainfall and temperature), as well as time (in order to investigate the presence of seasonal infestation) were conducted. The sta- tistical analysis was performed using the SPSS statistical package.

\section{RESULTS}

A total of 922 birds was examined from 1990 to 1995 . Fifty six specimens $(6.1 \%)$ were infested with I. auritulus and four specimens presented double infestation with Amblyomma sp. The access numbers of $I$. auritulus lots as well as their host, green area and collection date, are shown on Table I.

We also found 32 birds (3.5\% of the total) infested by 88 immature Amblyomma sp. ticks. The most infested park was the Passaúna (70 specimens collected in 15 birds). The number of Amblyomma sp. specimens and infested birds in the Barigui and Iguaçu parks were equivalent $(6 / 6)$, in the Reinhardt Maack (3/2), in the Barreirinha (1/1) and in the Primavera $(2 / 2)$. Due to the difficulty in identifying the immature stages of Amblyomma, only the data concerning the I. auritulus species was considered in this study. Moreover, birds host all the phases of their biological cycle.

The number of birds, examined and found to be infested by I. auritulus from the green areas are demonstrated in Table II. The Passaúna Park presented the largest number of $T$. rufiventris, examined with $22.5 \%(16 / 71)$ infested hosts. On the other hand, the Barigui Park presented 25\% of $T$. rufiventris infested (10/40), and the same was observed for the Reinhardt Maack Park (11/53, $20.8 \%$ ). The Iguaçu Park presented the smallest number of T. rufiventris examined, although $6.3 \%$ (1/16) of the hosts were infested. The Barreirinha and Primavera parks presented 6\% (3/50) and 6.8\% (4/59), infestion respectively.

The number and percentage of I. auritulus larvae, nymphs and females and the total tick/bird infestation indices are shown in Table III. $T$. rufiventris was more infested (87.3\%) by immature and adult forms of I. auritulus than any other host. The tick-host infestation index for $T$. rufiventris (2:1) was also observed for $T$. amaurochalinus and Conopophaga lineata.

The monthly rainfall indices and monthly average temperature from 1992 to 1995 are shown in Fig. 1.

Spearman rank correlations between the numbers of larvae, nymphs and females of I. auritulus, collected monthly from 1992 to 1995 (Fig. 2), and monthly meteorological data were calculated. The number of females increased significantly between September through November $(\mathrm{r}=0,645 ; \mathrm{p}=$ $0,007)$, and was not correlated with rainfall or temperature. Between larvae and nymphs, the correlation was significantly positive $(\mathrm{r}=0,764 ; \mathrm{p}=$ $0,001)$. Nevertheless, there was no monthly or sea- 
TABLE I

Material of Ixodes auritulus deposited in Museu de História Natural Capão da Imbuia, collected on birds from the city of Curitiba, State of Paraná, Brazil, from 1990 to 1995

\begin{tabular}{|c|c|c|c|c|}
\hline Lot number & Number of ticks & Hosts & Parks & Date \\
\hline MHNCI 91 & $1 \mathrm{~F}$ & Turdus albicollis & Passaúna & $05 / 12 / 90$ \\
\hline MHNCI 92 & $1 \mathrm{~F}$ & T. rufiventris & Passaúna & $05 / 12 / 90$ \\
\hline MHNCI 102 & $1 \mathrm{~N}, 1 \mathrm{~L}$ & Conopophaga lineata & Passaúna & $14 / 05 / 92$ \\
\hline MHNCI 93 & $1 \mathrm{~N}, 3 \mathrm{~L}$ & T. rufiventris & Passaúna & $14 / 05 / 92$ \\
\hline MHNCI 94 & $2 \mathrm{~N}, 6 \mathrm{~L}$ & T. rufiventris & Passaúna & $14 / 05 / 92$ \\
\hline MHNCI 103 & $1 \mathrm{~N}$ & Syndactyla rufosuperciliata & Passaúna & $14 / 05 / 92$ \\
\hline MHNCI 100 & $2 \mathrm{~N}, 2 \mathrm{~L}$ & T. rufiventris & Passaúna & $21 / 06 / 92$ \\
\hline MHNCI 101 & $4 \mathrm{~F}$ & T. rufiventris & Passaúna & $30 / 11 / 92$ \\
\hline MHNCI 518 & $2 \mathrm{~N}$ & T. amaurochalinus & Passaúna & $23 / 03 / 93$ \\
\hline MHNCI 543 & $1 \mathrm{~N}$ & Syndactyla rufosuperciliata & Barigui & $25 / 03 / 93$ \\
\hline MHNCI 572a & $1 \mathrm{~F}, 1 \mathrm{~N}$ & T. rufiventris & Iguaçu & $23 / 09 / 93$ \\
\hline MHNCI 573 & $1 \mathrm{~N}$ & Syndactyla rufosuperciliata & Barigui & $27 / 09 / 93$ \\
\hline MHNCI 574 & $1 \mathrm{~N}$ & T. rufiventris & Barigui & $27 / 09 / 93$ \\
\hline MHNCI 575 & $1 \mathrm{~F}, 1 \mathrm{~N}$ & T. rufiventris & Barigui & $27 / 09 / 93$ \\
\hline MHNCI 557 & $1 \mathrm{~N}$ & Syndactyla rufosuperciliata & Passaúna & $20 / 10 / 93$ \\
\hline MHNCI 558 & $1 \mathrm{~F}$ & T. rufiventris & Passaúna & $20 / 10 / 93$ \\
\hline MHNCI 576 & $1 \mathrm{~L}$ & T. rufiventris & Barigui & $22 / 10 / 93$ \\
\hline MHNCI 577 & $1 \mathrm{~F}, 1 \mathrm{~N}$ & T. rufiventris & Passaúna & $10 / 11 / 93$ \\
\hline MHNCI 578 & $1 \mathrm{~F}$ & T. rufiventris & Passaúna & $10 / 11 / 93$ \\
\hline MHNCI 579 & $1 \mathrm{~N}$ & T. rufiventris & Passaúna & $10 / 11 / 93$ \\
\hline MHNCI 580 & $1 \mathrm{~F}$ & Columbina talpacoti & Reinhardt Maack & $16 / 11 / 93$ \\
\hline MHNCI 581 & $1 \mathrm{~F}, 1 \mathrm{~N}$ & T. rufiventris & Reinhardt Maack & $16 / 11 / 93$ \\
\hline MHNCI 582 & $1 \mathrm{~F}$ & T. rufiventris & Reinhardt Maack & $16 / 11 / 93$ \\
\hline MHNCI 583 & $2 \mathrm{~F}$ & T. rufiventris & Reinhardt Maack & $16 / 11 / 93$ \\
\hline MHNCI 584 & $1 \mathrm{~F}$ & T. rufiventris & Reinhardt Maack & $16 / 11 / 93$ \\
\hline MHNCI 570 & $1 \mathrm{~N}$ & T. rufiventris & Passaúna & $06 / 07 / 94$ \\
\hline MHNCI 585 & $1 \mathrm{~F}$ & T. rufiventris & Passaúna & $14 / 10 / 94$ \\
\hline MHNCI 586 & $2 \mathrm{~F}, 1 \mathrm{~N}$ & T. rufiventris & Passaúna & $14 / 10 / 94$ \\
\hline MHNCI 587 & $1 \mathrm{~N}$ & T. rufiventris & Passaúna & $14 / 10 / 94$ \\
\hline MHNCI 588b & $2 \mathrm{~N}$ & T. rufiventris & Barigui & 19/10/94 \\
\hline MHNCI 589 & $2 \mathrm{~F}$ & T. rufiventris & Barigui & $19 / 10 / 94$ \\
\hline MHNCI 590 & $1 \mathrm{~F}$ & T. rufiventris & Barigui & $19 / 10 / 94$ \\
\hline MHNCI 591 & $2 \mathrm{~F}$ & T. rufiventris & Barigui & $19 / 10 / 94$ \\
\hline MHNCI 592 & $1 \mathrm{~L}$ & Basileuterus leucoblepharus & Barigui & $19 / 10 / 94$ \\
\hline MHNCI 593 & $1 \mathrm{~F}$ & T. rufiventris & Reinhardt Maack & $20 / 10 / 94$ \\
\hline MHNCI 594 & $1 \mathrm{~F}$ & T. rufiventris & Reinhardt Maack & $20 / 10 / 94$ \\
\hline MHNCI 595 & $1 \mathrm{~F}$ & T. rufiventris & Reinhardt Maack & $20 / 10 / 94$ \\
\hline MHNCI 596 & $1 \mathrm{~F}$ & T. rufiventris & Barigui & $18 / 11 / 94$ \\
\hline MHNCI 597 & $1 \mathrm{~F}$ & T. rufiventris & Barigui & $18 / 11 / 94$ \\
\hline MHNCI 598 & $1 \mathrm{~F}$ & T. rufiventris & Barigui & $18 / 11 / 94$ \\
\hline MHNCI 599 & $1 \mathrm{~F}$ & T. rufiventris & Reinhardt Maack & $22 / 11 / 94$ \\
\hline MHNCI 600 & $1 \mathrm{~F}$ & T. rufiventris & Reinhardt Maack & $22 / 11 / 94$ \\
\hline MHNCI 601 & $4 \mathrm{~F}$ & T. rufiventris & Reinhardt Maack & $22 / 11 / 94$ \\
\hline MHNCI 602 & $1 \mathrm{~F}, 1 \mathrm{~N}$ & T. rufiventris & Reinhardt Maack & $22 / 11 / 94$ \\
\hline MHNCI 603 & $1 \mathrm{~N}$ & T. rufiventris & Passaúna & $20 / 02 / 95$ \\
\hline MHNCI 604 & $1 \mathrm{~N}$ & Trichotraupis melanops & Barreirinha & $21 / 02 / 95$ \\
\hline MHNCI 605 & $2 \mathrm{~N}$ & T. rufiventris & Barreirinha & $05 / 04 / 95$ \\
\hline MHNCI 606 & $1 \mathrm{~N}$ & T. rufiventris & Primavera & $08 / 04 / 95$ \\
\hline MHNCI 649 & $2 \mathrm{~N}, 4 \mathrm{~L}$ & T. rufiventris & Primavera & $08 / 04 / 95$ \\
\hline MHNCI 650 & $1 \mathrm{~N}$ & T. rufiventris & Primavera & $08 / 04 / 95$ \\
\hline MHNCI 651 & $1 \mathrm{~N}$ & T. rufiventris & Primavera & $08 / 04 / 95$ \\
\hline MHNCI $607 \mathrm{c}$ & $1 \mathrm{~N}$ & T. rufiventris & Passaúna & $28 / 06 / 95$ \\
\hline MHNCI 608d & $8 \mathrm{~L}$ & T. rufiventris & Barreirinha & $29 / 06 / 95$ \\
\hline MHNCI 609 & $1 \mathrm{~N}$ & Clibanornis dendrocolaptoides & Passaúna & $10 / 08 / 95$ \\
\hline MHNCI 610 & $1 \mathrm{~F}$ & T. rufiventris & Barreirinha & $04 / 10 / 95$ \\
\hline MHNCI 611 & $1 \mathrm{~F}, 1 \mathrm{~N}$ & T. rufiventris & Passaúna & $07 / 10 / 95$ \\
\hline
\end{tabular}

Date: is represented by day, month, year; F: female; N: nymph; L: larva; double infestation with Amblyomma sp. is represented by a: $1 \mathrm{~L} ; \mathrm{b}: 1 \mathrm{~N} ; \mathrm{c}: 6 \mathrm{~L} ; \mathrm{d}: 1 \mathrm{~L}$. 
sonal significant correlation nor with any metereological data, although an increase in the larval and nymph numbers during the Autumm (and in nymphs during the Spring) was observed. The correlation between the mean temperatures and the rainfall was significantly negative $(r=0,706 ; p$ $=0,002)$, reflecting the decreased rainfall during the colder months.

\section{DISCUSSION}

There are two other Brazilian collections with I. auritulus material: the Instituto Butantan mite collection, with five immature specimens collected from Penelope superciliaris and Penelope sp. (Cracidae: Galliformes) birds, from the State of São Paulo, 1956 (Barros-Battesti \& Knysak 1999), and the Laboratório de Doenças Parasitárias of the Faculdade de Medicina Veterinária e Zootecnia, Universidade de São Paulo mite collection, with one female (collection no. 77) collected in September, 1997 from T. ruficapillus (Formicariidae: Passeriformes) from Herval, State of Rio Grande do Sul (Marcelo Bahia Labruna, pers. commun.). The specimens of I. auritulus collected in this study and their hosts shown on Table I, constitute the main Brazilian I. auritulus collection.

Considering the extension of the green areas and the study period (Table II), the Barreirinha $\left(275,380 \mathrm{~m}^{2}\right)$ and Primavera $\left(800,000 \mathrm{~m}^{2}\right)$ parks, studied only during 1995, presented a large number of investigated birds but only small infestation indices $(2.8 \%$ and $2.9 \%$ respectively). The Passaúna $\left(6,500.000 \mathrm{~m}^{2}\right)$ and Barigui $(1,400.000$ $\mathrm{m}^{2}$ ) parks were best represented in the number of samples of infested birds, with infestation indices of $8.3 \%$ and $7.8 \%$, respectively. The largest area, the Iguaçu Park $\left(8,264.316 \mathrm{~m}^{2}\right)$ presented the smallest number of infested birds with only one infested specimen (1\%). On the other hand, the park with the smallest area, Reinhardt Maack Park $\left(78,000 \mathrm{~m}^{2}\right)$, had the highest infestation index $(10 \%)$. Thus, the Reinhardt Maack, Passaúna and Barigui parks offer the best conditions for the continuation of bioecological studies of I. auritulus, due to the higher levels of infestation.

Marini et al. (1996) observed that several endemic birds of the Atlantic Forest from Paraná, showed high ectoparasite prevalence for some groups (e.g. $88.7 \%$ for feather mites during the Winter) or for specific host taxa (e.g. $85.3 \%$ for ticks on Dendrocolaptidae). In their study, these authors investigated the dense montain cloud forest area, located at $\approx 1,000 \mathrm{~m}$ above sea level, and collected 120 specimens of Amblyomma sp. larvae and a single Ixodes sp. nymph during the Winter. Nevertheless, they collected seven Ixodes sp. nymphs and a single Amblyomma sp. larvae dur- 
TABLE III

Number and \% of larvae, nymphs and females of Ixodes auritulus collected on bird species, and total tick/host infestation indices, from 1990 to 1995 in Curitiba, State of Paraná, Brazil

\begin{tabular}{|c|c|c|c|c|c|c|c|c|c|c|}
\hline \multirow[b]{3}{*}{ Hosts } & \multicolumn{9}{|c|}{ Ticks } & \multirow{3}{*}{$\begin{array}{l}\text { Total tick/host } \\
\text { infestation indices }\end{array}$} \\
\hline & \multirow[b]{2}{*}{ No. } & \multicolumn{2}{|c|}{ Larvae } & \multicolumn{2}{|c|}{ Nymphs } & \multicolumn{2}{|c|}{ Females } & \multicolumn{2}{|c|}{ Total } & \\
\hline & & No. & $\%$ & No. & $\%$ & No. & $\%$ & No. & $\%$ & \\
\hline Passeriformes & 55 & 26 & 25.7 & 36 & 35.6 & 39 & 38.6 & 101 & 99 & 1.8 \\
\hline Turdidae & 47 & 24 & 26.1 & 29 & 31.5 & 39 & 42.4 & 92 & 90.2 & 2 \\
\hline Turdus rufiventris & 45 & 24 & 27 & 27 & 30.3 & 38 & 42.7 & 89 & 87.3 & 2 \\
\hline Turdus albicolis & 1 & - & - & - & - & 1 & 100 & 1 & 1 & 1 \\
\hline Turdus amaurochalinus & 1 & - & - & 2 & 100 & - & - & 2 & 2 & 2 \\
\hline Formicariidae & 1 & 1 & 50 & 1 & 50 & - & - & 2 & 2 & 2 \\
\hline Conopophaga lineata & 1 & 1 & 50 & 1 & 50 & - & - & 2 & 2 & 2 \\
\hline Furnariidae & 5 & - & - & 5 & 83.3 & - & & 5 & 5 & 1 \\
\hline Syndactyla rufosuperciliata & 4 & - & - & 4 & 100 & - & - & 4 & 3.9 & 1 \\
\hline Clibanornis dendrocolaptoides & $s \quad 1$ & - & - & 1 & 100 & - & & 1 & 1 & 1 \\
\hline Emberizidae & 1 & - & - & 1 & 100 & - & - & 1 & 1 & 1 \\
\hline Trichothraupis melanops & 1 & - & - & 1 & 100 & - & - & 1 & 1 & 1 \\
\hline Parulidae & 1 & 1 & 100 & - & - & - & - & 1 & 1 & 1 \\
\hline Basileuterus leucoblepharus & 1 & 1 & 100 & - & - & - & - & 1 & 1 & 1 \\
\hline Columbiformes & 1 & - & - & - & - & 1 & 100 & 1 & 1 & 1 \\
\hline Columbidae & 1 & - & - & - & - & 1 & 100 & 1 & 1 & 1 \\
\hline Columbina talpacoti & 1 & - & - & - & - & 1 & 100 & 1 & 1 & 1 \\
\hline Total & 56 & 26 & 25.5 & 36 & 35.3 & 40 & 39.2 & 102 & 100 & 1.8 \\
\hline
\end{tabular}
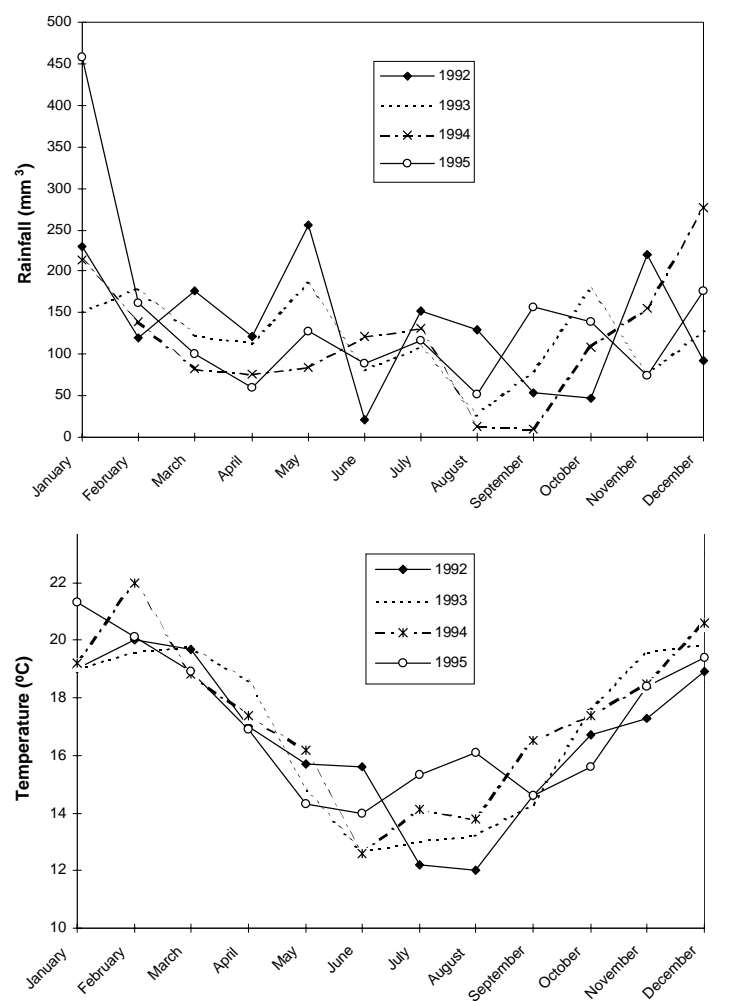

Fig. 1: monthly rainfall and average temperature from 1992 to 1995 in the city of Curitiba, State of Paraná, Brazil. ing the Summer, in the same area. We examined all the ticks collected during their study and identified none of the specimens of Ixodes as $I$. auritulus. Therefore, the Curitiba green areas appear to represent good distribution areas for this species.

The ectoparasites of Neotropical birds are poorly studied, even though in other regions, studies have demonstrated that ectoparasitism may decrease birds' reproductive success by increasing mortality rates or decreasing development rates of nestlings, and the ability to attract mates (Duffy 1983, Clayton 1990, Chapman \& George 1991). Nevertheless, the veterinary and medical importance of I. auritulus is not known (Durden \& Keirans 1996).

Regarding the correlation between monthly rainfall and average temperatures, from 1992 to 1995, with larvae, nymphs and female ticks monthly distribution (Figs 1,2), a positive significant correlation for females $(r=0,645 ; p=0,007)$ during the Spring months (from September to November) was observed. The numbers of larvae and nymphs showed peaks (especially nymphs) from March to June, and September to November). Since larvae and nymphs present corresponding peaks, there is a significant positive correlation between them. However, these numbers were not signifi- 

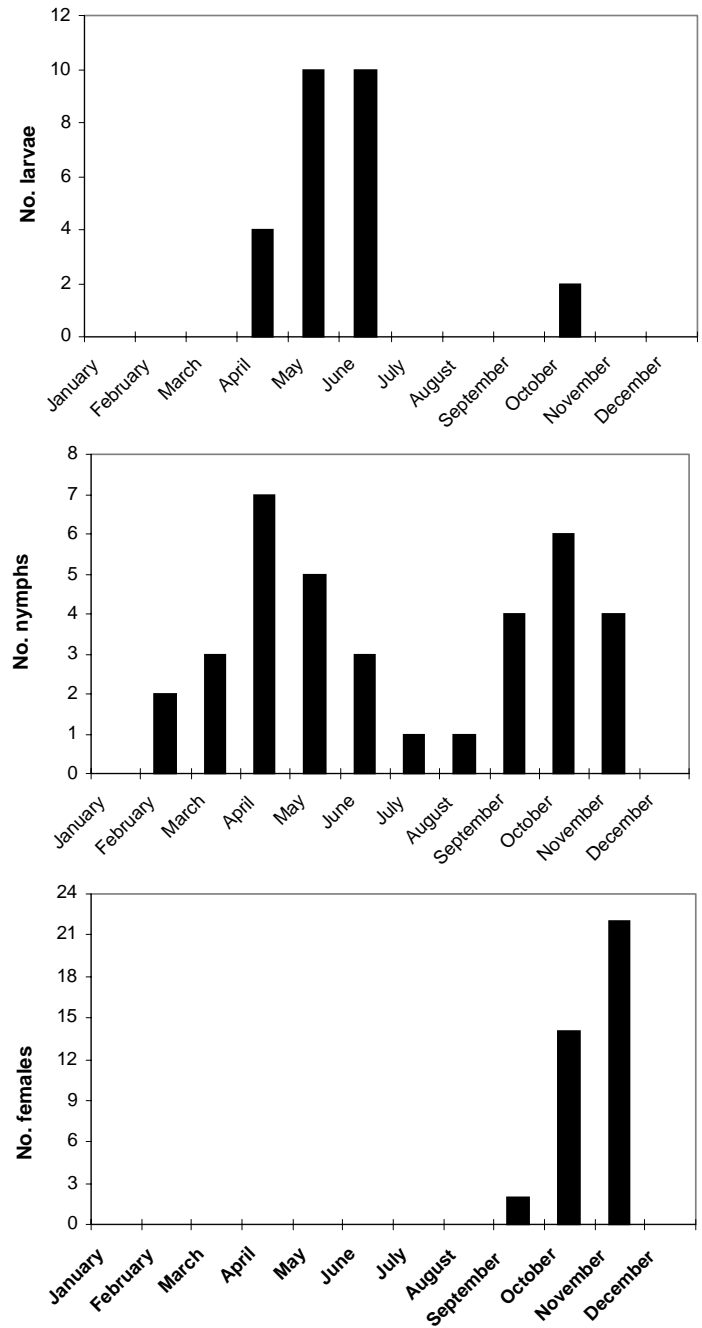

Fig. 2: monthly distribution of larvae, nymphs and females of Ixodes auritulus on birds collected from 1992 to 1995, in the city of Curitiba, State of Paraná, Brazil.

cant when correlated to the months of the year. In Paraná, in forest areas with Araucaria angustifolia, where the temperatures decrease between Autumn and Spring, I. auritulus, seems to have a longer biological cycle than other Brazilian Ixodes species, because larvae were most abundant during the Autumn of 1992 and in the Autumn and beginning of Winter of 1995. However, only two larvae were collected between 1993 and 1994, one specimen in each Spring (Table I, Fig. 2). Unfortunately, there are no other studies on the life cycle of other Brazilian Ixodes species and these results could be different for other areas.

In Southern Brazil, the I. auritulus hosts are mainly Passeriformes birds, and in the green areas of the city of Curitiba, this species infests mainly T. rufiventris (Table III). However, this tick also occurs in other geographic regions, on other bird orders, such as: Sphenisciformes, Falconiformes, Galliformes, Craciformes, Charadriiformes and Apodiformes (Cooley \& Kohls 1945, Arthur 1960).

Regarding host distribution, except for $C$. dendrocolaptoides, that has a limited distribution occurring from Argentina to Southern Brazil, including Rio Grande do Sul and Paraná, all those Passeriformes and Columbiformes birds are well distributed in South America. However, there are no records of migration between the countries (Meyer de Schauensee 1983). In Brazil, T. amaurochalinus does migrate, probably from South to North, up to the State of Amazonas (Sick 1984). By means of bird banding, carried out during this study, migration between parks was recorded only for T. rufiventris.

This study increases the gamut of host birds of I. auritulus for Brazil. The new records include the following bird families: Furnariidae, Parulidae and Emberizidae (Passeriformes) and Columbidae (Columbiformes). For Formicaridae and Turdidae, the following species are added: $C$. lineata e $T$. amaurochalinus, respectively, as hosts. This is the first report of I. auritulus on Columbina talpacoti.

One male of I. auritulus was recorded from Chile, from an unknown host and source (Kohls \& Clifford 1966). Since parthenogenesis has not been recorded for Ixodes (Woolley 1987, Oliver $\mathrm{Jr}$ 1989), the absence of males on the examined hosts ( $\mathrm{N}=922$ ) during this study, leads us to believe that its absence on hosts must be related to a possible dependence with a nest microhabitat, as a strategy for mating and not necessarily a direct interdependence with the host. However, these questions can only be answered by the continuation of this study in field and laboratory conditions.

\section{ACKNOWLEDGMENTS}

To Dalila Ribeiro Viana, biologist of the Museu de História Natural Capão da Imbuia, for the assistance in bird identification; to Rosana Ferrando, Isaura Camargo, Sebastião Pereira and Luiz Macedo for field assistance; to Dr Hilton F Japyassu, Instituto Butantan, for statistical assistance; to Dr João Luiz Horácio Faccini, Universidade Federal Rural do Rio de Janeiro, for the critical analysis of the manuscript.

\section{REFERENCES}

Arzua M, Barros DM, Linardi PM, Botelho JR 1994. Noteworthy records of Ixodes auritulus Neumann, 1904 (Acari, Ixodida) on birds from Paraná, Southern Brazil. Mem Inst Oswaldo Cruz 89: 129.

Arthur DR 1960. A review of some ticks (Acarina: Ixodidae) of sea birds. Part II. The taxonomic problems associated with the Ixodes-auritulus-percavatus group of species. Parasitology 50: 199-226.

Barros-Battesti DM, Knysak I 1999. Catalogue of the Brazilian Ixodes (Acari: Ixodidae) material in the 
mite collection of the Instituto Butantan, São Paulo, Brazil. Pap Avulsos Zool 41: in press.

Chapman BR, George JE 1991. The effects of ectoparasitism on Cliff Swallow growth and survival, p. 69-92. In JE Loye, M Zurk (eds), Bird-parasite Interactions: Ecology, Evolution and Behaviour, Oxford Univ Press, Oxford.

Clayton DH 1990. Mate choice in experimentally parasitized rock doves: lousy males lose. Am Zool 30: 251-262.

Clifford CM, Sonenshine DE, Keirans JE, Kohls GM 1973. Systematics of the subfamily Ixodinae (Acarina: Ixodidae). I. The subgenera of Ixodes. Ann Entomol Soc Am 66: 489-500.

Coelho MA 1990. Geografia do Brasil, 3rd ed., Moderna, São Paulo, 281 pp.

Cooley RA, Kohls, GM 1945. The genus Ixodes in North America. Nat Inst Health Bull 184: 1-246.

Duffy DC 1983. The ecology of tick parasitism on densely nesting Peruvian seabirds. Ecology 64: 110119.

Dumbleton LJ 1953. The ticks (Ixodoidea) of the New Zealand subregion. N Z Capes Exped Ser Bull 14: 128.

Dumbleton LJ 1961. The ticks (Acarina: Ixodoidea) of sea birds in the New Zealand waters. $N$ Z J Sci 4 : 760-769.

Durden LA, Keirans JE 1996. Nymphs of the Genus Ixodes (Acari: Ixodidae) of the United States: Taxonomy, Identification Key, Distribution, Hosts, and Medical/Veterinary Importance, Entomological Society of America, Lanham, Maryland, 95 pp.

IBGE 1995. Programa Versão DOS. Sistema de apresentação de dados CIVI - Cadastro de cidades e vilas, Rio de Janeiro.

Kohls GM, Clifford CM 1966. Three new species of Ixodes from Mexico and description of the male of I. auritulus auritulus Neumann, I. conepati Cooley and Kohls, and I. lasallei Mendez and Ortiz (Acarina: Ixodidae). J Parasitol 52: 810-820.

Maack R 1968. Geografia Física do Estado do Paraná, 2nd ed., José Olympio, Rio de Janeiro, 450 pp.

Marini MA, Reinert BL, Bornschein MR, Pinto JC, Pichorim MA 1996. Ecological correlates of ectoparasitism on Atlantic Forest birds, Brazil. Ararajuba 4: 93-102.

Mendez-Arocha M, Ortiz I 1958. Revision de las garrapatas venezuelanas del genero Ixodes Latr., y estudio de un nuevo Amblyomma. Mem Soc Cienc Nat La Salle 51: 196-208.

Meyer De Schauensee R 1983. A Guide to the Birds of South America, Filadelphia Academy of Natural Sciences, Filadelphia, 498 pp.

Nuttall GHF, Warburton C 1911. Monograph of the Ixodoidea. Part II. The Ixodidae, Cambridge University Press, London, 348 pp.

Oliver Jr JH 1989. Biology and systematics of ticks (Acari: Ixodida). Annu Rev Ecol Syst 20: 397-430.

Scherer Neto P, Straube FC 1995. Aves do Paraná. História, Lista Anotada e Bibliografia, Gráfica e Editora Logos Press, Campo Largo, 79 pp.

Sick H 1984. Ornitologia Brasileira, Vols 1 and 2, 3rd ed., Universidade de Brasília, Brasília, 827 pp.

Woolley TA 1987. Acarology. Mites and Human Welfare, Library of Congress Cataloging in Publication, Fort Collins, Colorado, 484 pp. 
